\title{
Diallel analysis of maize inbred lines for agronomic traits in nitrogen stress and optimal conditions
}

\author{
D. J. OGUNNIYAN*, D. K. OJO, S. A. OLAKOJO AND O.A. TALABI \\ (D.J.O \& S.A.O.: Institute of Agricultural Research and Training, Obafemi Awolowo University, \\ Ibadan, Nigeria; D.K.O\& O.A.T.: International Institute of Tropical Agriculture, Ibadan, \\ Nigeria) \\ *Corresponding author's email: dotunogunniyan@yahoo.com
}

\begin{abstract}
Increasing demand, soil cultivation pressure and adverse climate change effects necessitated maize production in nitrogen stress soils. This study examined the general combining ability (GCA) of 12 maize inbreds and specific combining ability of their crosses for agronomic traits under varied nitrogen conditions. GCA accounted for 53\% of the variation for grain yield (GY) under stress and $40 \%$ under optimal condition. GCA contributed over $59 \%$ for days to anthesis (DTA) and days to silking (DTS), anthesis-silking-interval (ASI) and ear aspect (EASP) under both conditions. BD74-165 and BD74-161 had positive significant GCA for GY under stress with TZEI12 under optimal and BD74-222 under both conditions. TZEI13 and TZEI16 had positive significant GCA for DTA and ASI under stress, and TZEI12, TZEI11 and BD74-161 under optimal. Additive genes control DTA, DTS and PH; non-additive genes were responsible for ASI, PASP and EASP while both additive and non-additive genes governed inheritance of GY, EH and leaf-senescence (SEN) under stress. Inheritance of GY, ASI, PH, PASP and EASP were due to non-additive genes; DTA and DTS to additive genes while additive and non-additive genes control EH and SEN under optimal condition. Inbreds with significant GCA can be parents for GY improvement under respective conditions.
\end{abstract}

Keywords: Combining ability; diallel; low nitrogen; maize lines; stress tolerance Original scientific paper. Received 06 Apr 18; revised 04 May 19

\section{Introduction}

Maize is well adapted to West and Central Africa (Ajala et al., 2007), but its mean grain yields range between 1.0 and 2.0 t ha $^{-1}$ compared to about $8.6 \mathrm{t} \mathrm{ha}^{-1}$ in the temperate countries (FAOSTAT, 2015). The low grain yield in Africa is partly ascribed to poor soil fertility status and management (Azeez \& Adetunji, 2007). Nutrients leaching and low level of soil organic matter have made $\mathrm{N}$ insufficiency a major constraint to sustainable smallholder maize production in Africa (Badu-Apraku et al., 2010; Ismaila et al., 2010). The annual loss of maize yield due to $\mathrm{N}$ stress varies from 10 to $50 \%$ (Wolfe et al., 1988). Maize performance varies within varieties across soil fertility levels from location to location and $\mathrm{N}$ use efficiency (Liang et al., 2005), because variation exists in gene expression of maize for low $\mathrm{N}$ tolerance. Nitrogen is a major nutrient responsible for

Ghana Jnl Agric. Sci. 54 (1), 10 - 23

GJAS is an Open Access Journal and distributed under the terms of the Creative Commons (CC) License [CC BY 4.0] 
high yields in maize. Availability of sufficient quantity of $\mathrm{N}$ during the growing period strongly influences the productivity of maize in respect of leaf production, stay green and high grain yield (Thomason et al., 2002). Moreover, poor adoption of fertilizers by African farmers due to the scarcity and high costs of the inorganic fertilizers had been a major constraint to manage soil $\mathrm{N}$ (Pinstrup-Andersen et al., 1999). CTA (2015) reported that fertilizers are applied at a rate of $10 \mathrm{~kg} \mathrm{ha}^{-1}$ in Africa compared to $100 \mathrm{~kg} \mathrm{ha}^{-1}$ worldwide, and $200 \mathrm{~kg} \mathrm{ha}^{-1}$ in Asia. Besides, inorganic fertilizers are harmful to the environment. In Africa, where fertilizer use is minimal, genetic approaches to yield maintenance at reduced rates of $\mathrm{N}$ are crucial. Expected high maize yields will be achieved at a reduced cost despite the poor soil fertility status or the hazardous effects of fertilizers.

Genetic analysis of the inheritance of important traits of a crop helps to reveal the combining ability which leads to the identification of the best parent combinations that result in superior performing hybrids (Bänziger \& Cooper, 2001). Combining ability of inbred lines, in turn, helps in determining the potential value of the variety development programme (Legesse et al., 2007) and reveals the nature of gene actions involved in the expression of traits. General combining ability is the mean performance of a line in all its crosses, expressed as a deviation from the mean of all crosses (Hallauer \& Miranda, 1988). General combining ability (GCA) is the main effect and indicate additive gene action while the SCA is associated with non-additive genetic effects controlling traits. The effects of SCA are used to identify the best cross combinations for hybrid production (Izge, 2007).

The diallel mating system is used for pre-selection of parents for developing hybrid varieties especially when there are no clear heterotic patterns among the parent lines. It involves crossing a certain number of inbred lines from the same gene pool to each other. Two major types of diallel system, namely full or half diallel, exist. It is full diallel or reciprocal when the lines are used as both female and male plants, but half or non-reciprocal cross when they are used either as male or female plants. The diallel mating system can also be used to estimate the GCA and SCA, determine the mode of inheritance of traits, genes that control the trait and gene effects. The mating system has been used extensively in genetic research to study the inheritance of important traits for stress tolerance among selected maize lines and to identify superior parents for hybrids or cultivar development (Olakojo \& Olaoye, 2005; Dhliwayo et al., 2009; Yallou et al., 2009; Badu-Apraku et al., 2011).

The objective of the study was to evaluate the combining ability and determine genes actions controlling the expression of grain yield and low $\mathrm{N}$ tolerance in crosses of local (IITA) and exotic (CIMMYT) maize inbred lines under $\mathrm{N}$ stress and optimal conditions using diallel analysis

\section{Materials and Methods}

12 yellow kernel inbred lines representing nine lines obtained from IITA, Nigeria and three elite lines originating from CIMMYT, Kenya were crossed in a non-reciprocal diallel mating system (Griffing, 1956) to generate 66 single cross hybrid maize. Description of the inbred lines used is shown in Table 1 . The 66 hybrids were evaluated along with four check hybrids under soil $\mathrm{N}$ stress and optimal conditions in Ibadan, Nigeria in 2014 and 2015. The experimental soil was purposely depleted of its native $\mathrm{N}$ by continuously planting maize at a very high population density without application of fertilizer, uprooting and removing the biomass completely after each cropping. This depletion 
procedure was repeated until the soil $\mathrm{N}$ was completely removed. Soil analysis was carried out to confirm the $\mathrm{N}$ status after each depletion process. The soil was depleted to about zero levels of $\mathrm{N}$.

The trial was laid out in $10 \times 7$ lattice design with three replicates. Plots consisted of two rows of $5 \mathrm{~m}$ long and $0.75 \mathrm{~m}$ apart, where plants were spaced $0.5 \mathrm{~m}$ in a row. Three seeds were sown and later thinned at two weeks after planting (WAP) to two stands per hill to attain plant population density of 53,333 plants ha ${ }^{-1}$. Two $\mathrm{N}$ concentrations, namely 30 and $90 \mathrm{~kg} \mathrm{~N}$ $\mathrm{ha}^{-1}$ were applied to denote $\mathrm{N}$ stress and optimal conditions, respectively. The fertilizer was applied in the form of NPK 15:15:15 at $30 \mathrm{~kg}$ $\mathrm{ha}^{-1}$ to each plot at three WAP. The optimal N plots received $60 \mathrm{~kg} \mathrm{~N} \mathrm{ha}^{-1}$ in the form of urea to bring the available $\mathrm{N}$ to $90 \mathrm{~kg} \mathrm{ha}^{-1}$ two weeks later. All the plots received $60 \mathrm{~kg} \mathrm{P} \mathrm{ha}^{-1}$ as single super phosphate $\left(\mathrm{P}_{2} \mathrm{O}_{5}\right)$ and $60 \mathrm{~kg} \mathrm{~K} \mathrm{ha}^{-1}$ as muriate of potash $\left(\mathrm{K}_{2} \mathrm{O}\right)$. Standard cultural practices were applied for field maintenance and harvesting practices according to IAR\&T (2010) package. This package included plowing and harrowing of land before planting, keeping the field weed-free by applying herbicides and hoeing. The crops were protected by hand picking and destruction of pests and roguing diseased plants as required and harvesting when the maize was dry.

\section{Data collection}

Data were collected on 10 plants from each plot under both $\mathrm{N}$ stress and optimal conditions in each year. Days to anthesis (DTA) and days to silking (DTS) were number of days from planting to the day $50 \%$ of the plants in a plot shed pollen, and had emerged silk, respectively. Anthesis-silking-interval (ASI) was calculated as the difference between DTS and DTA. Plant height $(\mathrm{PH})$ and ear height $(\mathrm{EH})$ were recorded as the height of the maize from ground level to the base of its tassel, and the base of the uppermost ear, respectively. Stay green (SG) was scored three times at eight days interval during the latter part of grain filling, according to Bänziger et al. (2000) on a scale of 0 to 10 , by dividing the percentage of total leaf area that was green by 10 . Scale $1=10 \%$ of leaves are green, $2=20 \%, 3=30 \%, 4=40 \%, 5=50 \%, 6=60 \%$, $7=70 \%, 8=80 \%, 9=90 \%$ and $10=100 \%$ of the leaves were green.

Plant aspect (PASP) was visually assessed on plot basis before harvest, after flowering (at brown silk stage) when plants were still green and ears fully developed on scale 1 to 5 where 1 was excellent; 5 was very poor. The PASP was the general appeal of the whole plants, based on the plant and ear heights, uniformity of the plant stands, reaction to diseases and insects as well as lodging. Ear aspect (EASP) was also visually scored on a scale of 1 to 5 where 1 was excellent; 5 was very poor. The score was taken on the pile of harvested ears of each plot when spread out and the general look of the ears was taken into account. Ear size, uniformity of colour and texture, grain fill, disease and insect damage were also considered for this score. Grain yield (GY), measured in $\mathrm{kg} \mathrm{ha}^{-1}$ adjusted to $15 \%$ moisture content was estimated from grain weight and percent moisture following Badu-Aparaku et al. (2012) as:

GY $\left(\mathrm{kg} \mathrm{ha}^{-1}\right)=\frac{\mathrm{GWT}(\mathrm{kg})}{7.5 \mathrm{~m}^{2}} \times \frac{(100-\mathrm{MC})}{(100-15 \%)} \times 10,000 \mathrm{~m}^{2}$

where $\mathrm{GWT}=$ Grain weight, $\mathrm{MC}=$ grain moisture content at harvest, seed moisture content at weighing $=15 \%$, plot area $=7.5 \mathrm{~m}^{2}$ and 1 ha $=10,000 \mathrm{~m}^{2}$. 


\section{Data analysis}

Analysis of variance was performed on the data collected for the 66 hybrids. Variation among hybrids was partitioned into that due to male and female parents and interaction between female and male parents. Main effects due to male and female were independent estimates of GCA whereas effects due to male $\times$ female were the SCA for each trait considered, for each $\mathrm{N}$ condition. Significance of effects of GCA of the parents and SCA of the hybrids were estimated for the traits from their mean square values adjusted for block effects for individual and across environments following Griffing's method 4 model 1 (fixed model) (Griffing, 1956) and DIALLEL SAS programme developed by Zhang et al. (2005) adapted to SAS software with PROC GLM in SAS (SAS Institute, 2009) using a RANDOM statement with TEST option. The high strength of GCA effects for a particular trait implies that additive genetic effects are more important for the inheritance of that trait, while non-additive genetic effects were more important for a trait for which SCA effects are predominant. The statistical model for the combined diallel analysis was as follows:

$\mathrm{Y}_{\mathrm{ijk}}=\mu+\mathrm{E}_{\mathrm{e}}+\mathrm{g}_{\mathrm{i}}+\mathrm{g}_{\mathrm{j}}+\mathrm{s}_{\mathrm{ij}}+\mathrm{g}_{\mathrm{eg}}+\mathrm{E}_{\mathrm{es}}+\varepsilon_{\mathrm{ijk}}$ where $Y_{i j k}$ is the observed measurement for the $\mathrm{ij}^{\text {th }}$ cross grown in the $\mathrm{k}^{\text {th }}$ environment; $\mu$ is the grand mean; $g_{i}$ and $g_{j}$ are the GCA effects; $s_{i j}$ is the SCA effects; ${ }_{\mathrm{g}} \mathrm{E}_{\text {eg }}$ is the interaction effect between GCA and the environment; $\mathrm{E}_{\mathrm{es}}$ is the interaction effect between SCA and the environment, and $\varepsilon_{\mathrm{ijk}}$ is the error term associated with the $\mathrm{ij}^{\text {th }}$ cross evaluated in the $\mathrm{k}^{\text {th }}$ replication and $\mathrm{E}_{\mathrm{e}}$ environment (Hallauer et al., 2010). On the combining ability effects: $\Sigma g_{i}=0$, and $\Sigma s_{i j}$ $=0$ for each $\mathrm{j}$.

\section{Results}

Analysis of variance of the agronomic traits of the hybrids under varied $N$ conditions

Environmental effects were highly significant for all the traits $(P<0.01)$ except SG and PASP under $\mathrm{N}$ stress (Table 2). Effects of genotype, $\mathrm{G} \times \mathrm{E}$, female, male and female $\times$ male were highly significant for GY and other traits considered. However, effects of environment $\times$ female $(\mathrm{E} \times \mathrm{F})$ and environment $\times$ male $(\mathrm{E} \times \mathrm{M})$ were significant $(P<0.05)$ for DTA, DTS and $\mathrm{PH}$ only. Analysis of data in optimal condition showed that environmental effects were significant for GY and other traits while the effects of genotype, $\mathrm{G} \times \mathrm{E}$, female, male as well as female $\times$ male were significant $(P<0.001)$ for all the traits. The $\mathrm{E} \times \mathrm{F}$ and $\mathrm{E} \times \mathrm{M}$ had non-significant effects for all the traits under optimal condition.

Combining ability for the traits of the inbred lines under varied $N$ conditions GCAs of the maize inbred lines

Significant and non-significant GCAs existed for the 12 inbred lines used in generating the hybrids as evaluated under $\mathrm{N}$ stress and optimal conditions for five agronomic traits considered as indices of low $\mathrm{N}$ tolerance in maize (Table 3). Significant GCAs for GY ranged from -1001.0 in TZEI11 to 491.4 in BD74161 under $\mathrm{N}$ stress. Inbred lines TZEI11 and TZEI124 had negative and significant GCA while the GCA of BD74-165 (327.10**), BD74$161\left(491.10^{* *}\right)$ and BD74-222 $\left(199.20^{* *}\right)$ were positive and significant for GY. Inbred lines TZEI13 and TZEI16 had positive and significant GCA for DTS and ASI while TZEI146 and BD74-165 had negative GCA for the traits. BD74-161 and BD74-222 had positive and significant GCA for GY and DTS while only BD74-165 had significant GCA for all the traits under the $\mathrm{N}$ stress. 
On the other hand, GCA for GY under optimal condition ranged from -591.9 for TZEI11 to 572.0 for TZEI12 (Table 3). Only inbred lines TZEI12 and BD74-222 had GCAs as positive and significant for GY while GCAs of TZEI10, TZEI11 and TZEI8 for the GY were negative and significant. TZEI12, TZEI11 and BD74-161 also had positive GCA for DTS and ASI while BD74-222 had positive GCA for GY and DTS $\left(0.736^{* *}\right)$ only. The significance of GCAs of TZEI13, TZEI12, TZEI11 and TZEI8 for SEN were positive while TZEI10, TZEI11 and TZEI8 had positive significant GCAs for PASP under the optimal $\mathrm{N}$ condition.

SCAs of the maize inbred lines in selected hybrids

The SCA effects for GY and some traits of the 12 maize inbred lines as components of selected hybrids are shown in Table 4 . The selected hybrids were those that had significant SCAs for GY, at least under stress or optimal condition. Positive and negative significant SCAs existed for GY, ASI, SG and PASP for the hybrids. The SCA for GY ranged from -1328 for TZEI146 $\times$ BD74-222 to 1275 for TZEI128 $\times$ BD74-161 under N stress. Hybrids TZEI128 $\times$ BD74161, TZEI11 $\times$ TZEI124, TZEI12 $\times$ BD74161, TZEI11 $\times$ TZEI16, TZEI8 $\times$ TZEI124 and TZEI13 $\times$ TZEI46 were prominent among those that had positive and significant SCA for GY. Hybrids TZEI13 × TZEI11, TZEI13 $\times$ TZEI146, TZEI124 $\times$ BD74165 and TZEI124 $\times$ BD74161 had negative significant SCAs for GY but significance of their SCA effects for SG and PASP were positive under $\mathrm{N}$ stress. Only TZEI146 × BD74222 had significant GCA for all the traits under the $\mathrm{N}$ stress condition.

The SCA for GY was from least (-1566) for TZEI13 $\times$ TZEI11 to highest (1561) for TZEI13 $\times$ TZEI12 under optimal N. TZEI13 $\times$ TZEI12, TZEI10 $\times$ BD74-165 and TZEI8 $\times$ TZEI16 had the highest positive and significant SCA while TZEI124 × BD74-165 had significant SCA for at least four out of the five traits under the $\mathrm{N}$ condition. It was also found that hybrids TZEI13 $\times$ TZEI128, TZEI11 $\times$ BD74161 and TZEI124 $\times$ BD74-222 had positive and significant SCA for GY under both $\mathrm{N}$ stress and optimal conditions.

Contributions of female and male GCA effects of inbred lines in varied $N$ conditions

Percentages sums of squares of GCA effects for GY and other traits of the hybrids evaluated under $\mathrm{N}$ stress and optimal conditions are shown in Table 5. The GCA explained greater than $50 \%$ of the variation for DTA, DTS and $\mathrm{PH}$; about $40 \%$ for EASP and only $25 \%$ for ASI, while the GCA effect was almost similar to that of SCA for GY, EH, SG and PASP under $\mathrm{N}$ stress condition. The sum of squares of $\mathrm{GCA}_{f}$ was less than that of $\mathrm{GCA}_{m}$ for SG, PASP and EASP but the two parameters were similar for DTS and ASI, while the effects of $\mathrm{GCA}_{f}$ were greater than that of $\mathrm{GCA}_{m}$ under $\mathrm{N}$ stress.

Under optimal $\mathrm{N}$, the GCA accounted for about $40 \%$ of the variation for GY, PH and PASP (Table 5). The GCA accounted for higher variation for DTA and DTS, but the effect was relatively similarly with SCA for $\mathrm{EH}$ and SG. The SCA effects were greater than $70 \%$ for ASI and EASP. However, the effects of GCA were less than that of $\mathrm{GCA}_{m}$ for DTA and DTS only and vice versa for GY, EH, SG, PASP and EASP under optimal condition. Sum of squares for $\mathrm{GCA}_{f}$ was similar to that of $\mathrm{GCA}_{m}$ for $\mathrm{PH}$ and ASI under the optimal condition. 


\section{Discussion}

Significant variations due to genotypes, environments and $\mathrm{G} \times \mathrm{E}$ observed for the $\mathrm{GY}$ and other traits under both $\mathrm{N}$ conditions indicate the presence of variability in the response of the hybrids to changes in $\mathrm{N}$ conditions. Maize performance has been reported to vary within varieties across soil fertility from location to location and $\mathrm{N}$ use efficiency (Liang et al., 2005). Hence, selection for promising hybrids under either of the $\mathrm{N}$ conditions is imperative. Moreover, the significant effects of male, female and female $\times$ male necessitated the estimation of combining the ability of the inbred lines for GY and other traits. The presence of non-significant main effect $(\mathrm{GCA}) \times$ environment under each $\mathrm{N}$ condition suggests that the performance of both male and female were stable across the years. Therefore, the selection of parent lines for hybrids can be done under various $\mathrm{N}$ conditions in any of the two years with respect to the traits.

The significant interaction effects such as GCA $\times$ environment for DTA, DTS and PH under $\mathrm{N}$ stress underlines the sensitivity of maize to $\mathrm{N}$ thereby exhibiting differential responses in different years. This was buttressed by the fact that the GCA $\times$ environments were not significant for all the traits under an optimal condition where a higher amount of $\mathrm{N}$ was available. According to the results of this study, the selection of parents based on the flowering traits under $\mathrm{N}$ stress is important for each year. Flowering traits have been suggested as selection indices for low $\mathrm{N}$ tolerance (Bänziger et al., 2000). This may be responsible for the variability due to the GCA $\times$ environments for the flowering traits under the $\mathrm{N}$ stress.

The GCAs of the inbred lines varied widely, from low to high and from significant to not significant in the crosses they were involved under different $\mathrm{N}$ conditions. The significant effects of GCA indicate that at least one of the maize lines differs in the content of favorable genes with additive effects. High GCA effects for GY and other traits in many of the parents indicates good general combination under the two $\mathrm{N}$ conditions and presence of heterotic response for the traits. However, the variation was wider under $\mathrm{N}$ stress than optimal condition, hence $\mathrm{N}$ stress provided a greater prospect for the expression and combination of genes in crosses. Three inbred lines namely, BD74-165, BD74-161 and BD74-222 exhibited high positive GCA effects for GY under N stress while TZEI12 and BD74-222 had high GCA effects under optimal. Hence, the inbred lines are suitable as parents for yield improvement in the respective $\mathrm{N}$ conditions. It has earlier been reported that lines derived from the same population may have either good or poor general combining ability (Sharma \& Garg, 2002; Lubadde et al., 2016). On the other hand, the high GCA obtained for exotic lines evaluated in this study emphasized the importance of novel alleles in CIMMYT (exotic) lines in maize improvement in Nigeria under both $\mathrm{N}$ conditions.

Highly positive and significant GCA effects of inbred lines TZEI13 and TZEI16 for DTA and ASI classified the lines in same maturity class under $\mathrm{N}$ stress while TZEI12, TZEI11 and BD74-161 were grouped together under optimal condition. Their combining ability will enhance synchronization during pollination. This indicates the presence of source from which genes can be drawn and manipulated for better pollination especially in areas where rainfall is not reliable. Bello and Olaoye (2009) also reported positive and significance of GCA effects for DTS in maize improvement. Incidentally, none of the two inbred lines (TZEI13 and TZEI146) that had significant GCA for flowering had significant GCA for GY under N stress. Inbred lines BD74165 and BD74222 
also had opposite significance for GY and flowering traits under the condition. Likewise, TZEI11 had negative significant GCA for GY but positive GCA for all other traits under optimal condition. Hybridization can therefore be made among selected inbred lines for desired traits. For instance, lines TZEI11, TZEI124, TZEI10 and TZEI8 had negative significant GCAs for GY, DTS or ASI, but could be useful in hybridization with other inbred lines that have high GY attribute. These inbred lines could be crossed with other promising ones to generate early maturity and high yielding hybrids.

The GCA effect was higher than that of SCA for DTA, DTS and PH confirming the predominance of additive genes actions for the inheritance of the traits but non-additive for ASI, PASP and EASP while both additive and non-additive genes govern inheritance of the GY, EH and SG under N stress. Derera et al. (2008); Senthil and Bharthi (2009) in their studies observed additive and non-additive effects were important for DTA, DTS and ASI of maize under stress. Nass et al. (2000) have also reported that both additive and non-additive effects are important for identifying promising parental lines and productive hybrids. The sum of squares of SCA for GY, ASI, PH, PASP and EASP were higher than those of GCA indicating non-additive genes control the traits while additive gene actions were responsible for the inheritance of DTA and DTS under optimal condition. The EH and SG had GCA effects similar to the SCA, hence the traits are governed by both additive and non-additive genes under the $\mathrm{N}$ condition. The SCA effects under both conditions were high especially, for GY, ASI and PASP indicating good specific combination for the trait. This also suggests that non-additive gene effects also played a major role in the expression of GY among crosses in respective $\mathrm{N}$ conditions. Non-additive gene action in inheritance of low $\mathrm{N}$ tolerance is exhibited by hybrids TZEI8 $\times$ TZEI124, TZEI11 $\times$ TZEI124, TZEI11 $\times$ TZEI16, TZEI128 $\times$ BD74161, TZEI12 $\times$ BD74161 and TZEI13 $\times$ TZEI46 because of their significant SCA under $\mathrm{N}$ stress condition. Therefore, they could be utilized as sources of inbred line extraction for the development of high yielding varieties for cultivation in $\mathrm{N}$ deficient soils. The TZEI13 $\times$ TZEI12, TZEI10 $\times$ BD74165 and TZEI8 $\times$ TZEI16 top the list of good combiners for GY for their significant SCA under optimal N while hybrids TZEI13×TZEI128, TZEI11×BD74161 and TZEI124 $\times$ BD74-222 are suitable for both $\mathrm{N}$ stress and optimal conditions. Betran et al. (2003) had earlier emphasized the importance of non-additive genes actions among maize inbred lines and hybrids in low $\mathrm{N}$ environments. Maize GY and flowering traits have been reported to be under the control of non-additive genes actions (Aminu et al., 2014; Pádua et al., 2016).

The sum of squares for $\mathrm{GCA}_{f}$ was less than $\mathrm{GCA}_{m}$ for all the traits except SG, PASP and EASP under N stress and DTA and DTS under optimal $\mathrm{N}$ indicating large genetic variability of female than the male contribution for the traits in the respective $\mathrm{N}$ conditions. The $\mathrm{GCA}_{f}$ and $\mathrm{GCA}_{m}$ had similar effects for DTS and ASI under $\mathrm{N}$ stress, as well as ASI and $\mathrm{PH}$ under optimal $\mathrm{N}$ condition. This means that both male and female contributed almost equally to the genetic variability among the hybrids for the traits. Contributions of female were more important in gene expression for yield, growth and flowering of the hybrid maize under low $\mathrm{N}$, but for all the traits except flowering under optimal condition. This may imply that maternal effects influence the expression of these traits. 
Derera et al. (2008) had earlier reported higher female GCA effects compared to male GCA effects for ASI.

\section{Conclusion}

Inbred lines BD74-165 and BD74-161 were best combiners under $\mathrm{N}$ stress, TZEI12 under optimal condition while BD74222 is promising under both $\mathrm{N}$ conditions. Hence, these lines can be used as parents for yield improvement in respective $\mathrm{N}$ conditions. Additive gene actions control DTA, DTS and PH; non-additive gene effects were responsible for ASI and EASP while both additive and non-additive gene actions were responsible for the inheritance of GY, EH and SG under $\mathrm{N}$ stress. Inheritance of GY, ASI, PH, PASP and EASP was due to non-additive gene actions; those for DTA and DTS was due to additive genes actions while additive and non-additive genes control $\mathrm{EH}$ and SG under optimal condition. Hence, these lines are suitable for the development of commercial hybrids for cultivation in respective $\mathrm{N}$ conditions. Females contributed more than males in the genes expression for GY and most other traits in the two $\mathrm{N}$ conditions. Exotic inbred lines are useful in maize improvement programmes for low $\mathrm{N}$ tolerance.

\section{Acknowledgement}

The authors thank personnel in Maize Improvement Programme of Institute of Agricultural Research and Training, Ibadan, Nigeria for their help with fieldwork. Many thanks to IITA and CIMMYT for providing seeds for the study. This research was supported by the Institute of Agricultural Research and Training, Obafemi Awolowo University, Ibadan, Nigeria.

\section{REFERENCES}

Ajala, S.O., Menkir, A., Kamara, A.Y., Alabi, S.O. \& Abdulai, M.S. (2007) Breeding strategies to improve maize for adaptation to low soil nitrogen in West and Central Africa. Proceedings of African Crop Science Conference. Egypt. 8, $87-94$.

Aminu, D., Dawud, M.A. \& Modu, A. (2014) Combining ability and heterosis for different traits in maize (Zea mays L.) under drought stress in Sudan Savanna of Borno State, Nigeria. J. Plant Breed. Crop Sci. 6 (10), 128 - 134.

Azeez, J.O. \& Adetunji, M.T. (2007) Nitrogen-use efficiency of maize genotypes under weed pressure in a tropical alfisol in Northern Nigeria. Tropicultura 25 (3), $174-179$.

Badu-Apraku, B., Menkir, A., Ajala, S., Akinwale, R., Oyekunle, M. \& Obeng-Antwi, K. (2010) Performance of tropical early-maturing maize cultivars in multiple stress environments. Can. J. Plant Sci. 90, $831-852$.

Badu-Apraku, B., Oyekunle, M., Akinwale, R. \& Fontem Lum, A. (2011) Combining ability of early-maturing white maize inbred under stress and non-stress environments. Agro. J. 103, 544 -557 .

Badu-Apraku, B., Fakorede, M.A.B., Menkir, A. \& Sanogo, D. (2012) Conduct and management of maize field trials. IITA, Ibadan, Nigeria. pp. 59.

Bänziger, M. \& Cooper, M.E. (2001) Breeding for low-input conditions and consequences for participatory plant breeding-examples from tropical maize and wheat. Euphytica, 122, 503 $-519$.

Bänziger, M., Edmeades, G.O., Beck, D. \& Bellon, M. (2000) Breeding for drought and nitrogen stress tolerance in maize: From theory to practice. CIMMYT, Mexico D.F. pp. 68.

Bello, O.B. \& Olaoye, G. (2009) Combining ability for maize grain yield and other agronomic characters in a typical Southern Guinea 
Savanna ecology of Nigeria. Afr. J. Bio. 8 (11), $2518-2522$.

Betran, F.J., Ribaut, J.M., Beck, D. ${ }^{1} \&$ Gonzalez de Leon, D. (2003) Genetic diversity, specific combining ability and heterosis in tropical maize under stress and non-stress environments. Crop Sci. 43, $797-806$.

CTA. (2015) Access to fertilizers: Finding the right path. CTA Spore, Agricultural and Rural development in ACP countries 176, 3 - 4.

Derera, J., Tongoona, P., Vivek, B.S. \& Laing, M.D. (2008) Gene action controlling grain yield and secondary traits in Southern African maize hybrids under drought and non-drought environments. Euphytica, 162 (3), 411 - 422.

Dhliwayo, T., Pixley, K., Menkir, A. \& Warburton, M. (2009) Combining ability, genetic distances and heterosis among elite CIMMYT and IITA tropical maize inbred lines. Crop Sci. 49, 1201 -1210 .

FAOSTAT. (2015) Statistical Database of the Food and Agriculture of the United Nations. http:// www.fao.org. (Downloaded 10 April 2017).

Griffing, B. (1956) Concepts of general and specific combining ability in relation to diallel crosses system. Austr. J. Bio. Sci. 9, $463-493$.

Hallauer, A.R. \& Miranda Filho, J.B. (1988) Quantitative genetics in maize breeding, (2nd ed.) Iowa State University Press, Ames. pp. 468.

Hallauer, A.R., Carena, M.J. \& Miranda Filho, J.B. (2010) Quantitative genetics in maize breeding. Science+Business Media. Iowa State University Ames, Iowa 50010.

IAR\&T. (2010) Institute of Agricultural Research \& Training. Farmers' Guide Series 1. No. 4: Guide on maize production. Obafemi Awolowo University, Ibadan. pp. 7.

Ismaila, U., Gana, A.S., Tswanya, N.M. \& Dogara, D. (2010) Cereals production in Nigeria: Problems, constraints and opportunities for betterment. Afr. J. Agric. Res. 5 (12), $1341-1350$.
Izge, A.U., Kadams, A.M. \& Gungula, D.T. (2007) Heterosis and inheritance of quantitative characters in diallel cross of pearl millet (Pennisetum glaucum L). J. Agro. 6 (2), 278 - 285.

Legesse, B.M., Myburg, A.A., Pixley, K. \& Botha, A.M. (2007) Genetic diversity of African maize inbred lines revealed by SSR markers. Hereditas 144, 10 - 17.

Liang, C., Guohua, M.I., Jiansheng, L.I., Fanjun, C. \& Fusuo, Z. (2005) Genetic analysis of maize root characteristics in response to low nitrogen stress. Plant Soil 276 (2), 369 - 382.

Lubadde, G., Tongoona, P., Derera, J. \& Sibiya, J. (2016) Combining ability and heterosis for grain yield and rust resistance in pearl millet. $J$. Agric. Sci. 8 (7), 80 - 96.

Nass, L., Lima, M., Venconvsky, R. \& Gallo, P. (2000) Combining ability of inbred lines evaluated in three environments in Brazil. Sci. Agr. 57(1), $129-134$.

Olakojo, S.A. \& Olaoye, G. (2005) Combining ability for grain yield, agronomic traits and Striga lutea tolerance of maize hybrids under artificial striga infestation. Afr. J. Biol. 4 (9), 984 - 988.

Pádua, J.M.V., Das Graças Dias, K.O., Pastina, M.M., de Souza, J.C., Queiroz, V.A.V., da Costa, R.V. da Silva, M.B.P. \& Ribeiro, C.A.G. (2016) A multi-environment trials diallel analysis provides insights on the inheritance of fumonisin contamination resistance in tropical maize. Euphytica 211 (3), 277 - 285.

Pinstrup-Andersen, P., Pandya-Lorch, R. \& Rosegrant, M.W. (1999) World Food Prospects: Critical Issues for the Early 21st Century. Washington D.C. International Food and Policy Research Institute. pp. 30.

SAS Institute. (2009) SAS Institute user's guide: Statistics, version 9.0. SAS Institute Incorporated, Cary, North Carolina, USA, pp. 1028.

Sharma, A.K. \& Garg, D. (2002) Genetic variability in wheat (Triticum aestivum L.) crosses under 
different normal and saline environments. Ann. Agric. Res. 23 (3), 497 - 499.

Senthil, K.P. \& Bharthi, P. (2009) Studies on relationship between GCA and SCA effects in maize (Z. mays L.). Electr. J. Plant Breed. 1, 24-27.

Thomason, W.E., Raun, W.R., Johnson, G.V., Freeman, K.W., Wynn, K.J. \& Mullen, R.W. (2002) Production system techniques to increase nitrogen-use efficiency in winter wheat. J. Plant Nutr. 25, $2261-2283$.

Wolfe, D.W., Henderson, D.W., Hsiao, T.C. \& Alvio, A. (1988) Interactive water and nitrogen ef- fects on maize. II. Photosynthetic decline and longevity of individual leaves. Agro. J. 80, 865 -870 .

Yallou, C.G., Menkir, A., Adetimirin, V.O. \& Kling, J.G. (2009) Combining ability of maize inbred lines containing genes from Zea diploperennis for resistance to Striga hermonthica (Del.) Benth. Plant Breed. 128, 143 - 148.

Zhang, Y., Kang, M.S. \& Lamkey, K.R. (2005) DIALLEL-SAS05: A comprehensive programme for Griffing's and Gardner-Eberthart Analyses. Agro. J. 97, 1097 - 1106.

TABLE 1

Description and sources of the maize inbred lines used for hybrids development using diallel mating system

\begin{tabular}{lllll}
\hline No. & Inbred line & Pedigree & Source & Low- $N$ \\
\hline 1 & TZEI8 & TZE-Y Pop STR C $\mathrm{S}_{6}$ Inbred 62-3-3 & IITA & Tolerant \\
2 & TZEI10 & TZE-Y Pop STR C $\mathrm{S}_{6}$ Inbred 152 & IITA & Tolerant \\
3 & TZEI11 & TZE Comp5-Y C $6 \mathrm{~S}_{6}$ Inbred 8 & IITA & Tolerant \\
4 & TZEI12 & TZE Comp5-Y C $\mathrm{S}_{6}$ Inbred 8 & IITA & Tolerant \\
5 & TZEI13 & TZE Comp5-Y C $6 \mathrm{~S}_{6}$ Inbred 12 & IITA & Tolerant \\
6 & TZEI16 & TZE Comp5-Y C6 S6 Inbred 31 & IITA & Tolerant \\
7 & TZEI124 & TZE-Y Pop STR C $\mathrm{S}_{6}$ Inbred 3-1-3 & IITA & Tolerant \\
8 & TZEI128 & TZE-Y Pop STR C $\mathrm{S}_{6}$ Inbred 10-4-4 & IITA & Tolerant \\
9 & TZEI146 & TZE-Y Pop STR C $\mathrm{S}_{6}$ Inbred 21-1-3 & IITA & Tolerant \\
10 & BD74-165 & (DTPYC9-F74-3-4-1-3-B)-B & CIMMYT & Tolerant \\
11 & BD74-161 & (DTPYC9-F46-3-9-1-1-B)-B & CIMMYT & Susceptible \\
12 & BD74-222 & (CLYN262)-B & CIMMYT & Susceptible \\
\hline
\end{tabular}

IITA, CIMMYT indicate International Institute of Tropical Agriculture, International Maize and Wheat Improvement Centre, respectively 
TABLE 2

Mean squares of traits from combined analyses of variance

for the hybrids under N stress and optimal conditions in 2014 and 2015

\begin{tabular}{|c|c|c|c|c|c|c|c|c|c|c|}
\hline Source of variation & $d f$ & Grain yield & $D T A$ & DTS & $A S I$ & $\begin{array}{l}\text { Plant } \\
\text { height }\end{array}$ & $\begin{array}{c}\text { Ear } \\
\text { height }\end{array}$ & $S G$ & $P A S P$ & $E A S P$ \\
\hline \multicolumn{11}{|c|}{$\mathrm{N}$ stress condition $\left(30 \mathrm{~kg} \mathrm{~N} \mathrm{ha}^{-1}\right)$} \\
\hline Environment (Env.) & 1 & $23322062.28^{* * * *}$ & $49.30^{* * *}$ & $50.79^{* * * *}$ & $0.011^{* * * *}$ & $998.12^{* *}$ & $429.53^{* *}$ & $0.16^{\text {ns }}$ & $0.00^{\mathrm{ns}}$ & $4.52^{* * * *}$ \\
\hline Replicate (Env.) & 4 & $43422.62^{\mathrm{ns}}$ & $1.06^{\mathrm{ns}}$ & $1.11^{\mathrm{ns}}$ & $0.032^{\mathrm{ns}}$ & $540.05^{* * *}$ & $316.98^{* * * *}$ & $0.75^{*}$ & $0.07^{\mathrm{ns}}$ & $0.20^{\mathrm{ns}}$ \\
\hline Block (Env. ×replicate) & 36 & $120486.98^{\mathrm{ns}}$ & $1.12^{\mathrm{ns}}$ & $1.06^{\mathrm{ns}}$ & $0.273^{\mathrm{ns}}$ & $212.28^{* * *}$ & $49.05^{* *}$ & $0.34^{\mathrm{ns}}$ & $0.10^{\mathrm{ns}}$ & $0.10^{\mathrm{ns}}$ \\
\hline Genotype & 69 & $1047433.3^{* * *}$ & $6.36^{* * * *}$ & $8.34^{* * * *}$ & $0.88^{* * *}$ & $898.56^{* * * *}$ & $178.10^{* * * *}$ & $0.92^{* * *}$ & $0.30^{* * * *}$ & $0.64^{* * *}$ \\
\hline Genotype $\times$ Env. & 69 & $1146459.1^{* * * *}$ & $4.13^{* * * *}$ & $5.35^{* * *}$ & $1.08^{* * *}$ & $509.15^{* * *}$ & $119.24^{* * *}$ & $0.55^{* * *}$ & $0.20^{*}$ & $0.48^{* * * *}$ \\
\hline Female & 10 & $7662155.00^{* *}$ & $23.50^{* *}$ & $22.17^{*}$ & $1.04^{* *}$ & $4484.35^{* * * *}$ & $615.65^{* * * *}$ & $2.34^{* * * *}$ & $1.18^{*}$ & $1.25^{* *}$ \\
\hline Male & 10 & $2802340.00^{*}$ & $20.32^{*}$ & $22.04^{*}$ & $1.17^{* * *}$ & $1983.94^{*}$ & $366.59^{*}$ & $4.30^{* * *}$ & $1.76^{* *}$ & $2.57^{*}$ \\
\hline Female $\times$ Male & 45 & $2020071.00^{* * * *}$ & $4.08^{* * * *}$ & $5.91^{* * *}$ & $1.49^{* * *}$ & $825.03^{* * * *}$ & $256.40^{* * * *}$ & $1.35^{* * *}$ & $0.73^{* * * *}$ & $1.35^{*}$ \\
\hline Env. $\times$ Female & 10 & $1208384.00^{\mathrm{ns}}$ & $4.03^{*}$ & $5.58^{*}$ & $0.21^{\mathrm{ns}}$ & $412.03^{*}$ & $52.45^{\mathrm{ns}}$ & $0.16^{\mathrm{ns}}$ & $0.21^{\mathrm{ns}}$ & $0.18^{\mathrm{ns}}$ \\
\hline Env. $\times$ Male & 10 & $824286.00^{\mathrm{ns}}$ & $6.70^{*}$ & $6.57^{*}$ & $0.41^{\mathrm{ns}}$ & $450.50^{*}$ & $105.24^{\mathrm{ns}}$ & $0.10^{\text {ns }}$ & $0.25^{\mathrm{ns}}$ & $0.70^{\mathrm{ns}}$ \\
\hline Env. $\times$ Female $\times$ Male & 45 & $552995.00^{* * * *}$ & $1.31^{\mathrm{ns}}$ & $1.51^{*}$ & $0.26^{\mathrm{ns}}$ & $192.64^{*}$ & $79.86^{* *}$ & $0.24^{\text {ns }}$ & $0.16^{* *}$ & $0.42^{* * *}$ \\
\hline Pooled error & 224 & 102919.10 & 1.02 & 0.90 & 0.21 & 144.21 & 47.14 & 0.28 & 0.90 & 0.12 \\
\hline \multicolumn{11}{|c|}{ Optimal condition $\left(90 \mathrm{~kg} \mathrm{~N} \mathrm{ha}^{-1}\right)$} \\
\hline Environment (Env.) & 1 & $26790246.3^{* * *}$ & $69.96^{* * *}$ & $87.56^{* * *}$ & $0.91^{*}$ & $212.42^{* *}$ & $684.78^{* * *}$ & $2.56^{* * *}$ & $0.78^{* * * *}$ & $3.36^{* * *}$ \\
\hline Replicate (Env.) & 4 & $255879.5^{\mathrm{ns}}$ & $12.00^{* * *}$ & $10.39^{* * * *}$ & $0.30^{\text {ns }}$ & $690.60^{* * * *}$ & $460.14^{* * * *}$ & $0.93^{* * * *}$ & $0.45^{* * * *}$ & $0.04^{\mathrm{ns}}$ \\
\hline Block (Env. ×replicate) & 36 & $170945.3^{\text {ns }}$ & $1.17^{\mathrm{ns}}$ & $1.12^{\text {ns }}$ & $0.29^{*}$ & $106.73^{\text {ns }}$ & $36.69^{\mathrm{ns}}$ & $0.20^{\text {ns }}$ & $0.11^{\mathrm{ns}}$ & $0.07^{\mathrm{ns}}$ \\
\hline Genotype & 69 & $1899724.8^{* * * *}$ & $5.90^{* * * *}$ & $8.77^{* * *}$ & $1.21^{* * *}$ & $905.44^{* * *}$ & $222.77^{* * *}$ & $0.87^{* * *}$ & $0.32^{* * *}$ & $0.69^{* * *}$ \\
\hline Genotype $\times$ Env & 69 & $1643032.5^{* * * *}$ & $3.41^{* * * *}$ & $5.23^{* * * *}$ & $0.70^{* * *}$ & $467.45^{* * *}$ & $115.09^{* *}$ & $0.46^{* * *}$ & $0.25^{* * * *}$ & $0.51^{* * *}$ \\
\hline Female & 10 & $6683783.0^{* *}$ & $14.45^{*}$ & $18.44^{*}$ & $1.46^{* *}$ & $1331.42^{* * * *}$ & $534.19^{* * * *}$ & $2.68^{* *}$ & $3.06^{* * *}$ & $3.30^{*}$ \\
\hline Male & 10 & $2258967.0^{*}$ & $22.48^{* *}$ & $27.45^{* * * *}$ & $1.25^{* *}$ & $1268.88^{* * *}$ & $347.14^{* *}$ & $1.66^{* *}$ & $1.08^{* *}$ & $1.52^{* *}$ \\
\hline Female $\times$ Male & 45 & $3023169.0^{* * * *}$ & $4.90^{* * *}$ & $7.07^{* * *}$ & $1.59^{* * *}$ & $928.66^{* * * *}$ & $233.42^{* *}$ & $0.93^{* * * *}$ & $1.38^{* * * *}$ & $2.65^{* * * *}$ \\
\hline Env. $\times$ Female & 10 & $1298058.0^{\mathrm{ns}}$ & $3.16^{\mathrm{ns}}$ & $3.90^{\text {ns }}$ & $0.20^{\text {ns }}$ & $101.00^{\mathrm{ns}}$ & $45.04^{\mathrm{ns}}$ & $0.42^{\text {ns }}$ & $0.31^{\mathrm{ns}}$ & $0.77^{\mathrm{ns}}$ \\
\hline Env. $\times$ Male & 10 & $471267.0^{\text {ns }}$ & $3.19^{\text {ns }}$ & $2.86^{\mathrm{ns}}$ & $0.20^{\text {ns }}$ & $241.52^{\mathrm{ns}}$ & $69.50^{\text {ns }}$ & $0.26^{\text {ns }}$ & $0.19^{\text {ns }}$ & $0.26^{\mathrm{ns}}$ \\
\hline Env. $\times$ Female $\times$ Male & 45 & $882175.0^{* * * *}$ & $2.07^{* * * *}$ & $1.91^{* * * *}$ & $0.18^{\mathrm{ns}}$ & $166.91^{\mathrm{ns}}$ & $92.76^{* *}$ & $0.27^{*}$ & $0.28^{* * * *}$ & $0.36^{* * * *}$ \\
\hline Pooled error & 224 & 203684.5 & 0.98 & 0.96 & 0.20 & 142.98 & 50.12 & 0.17 & 0.01 & 0.11 \\
\hline
\end{tabular}

ns, ${ }^{*},{ }^{* *},{ }^{* * *}$ and df are not significant, significant at $5 \%, 1 \%, 0.1 \%$ degrees of freedom, respectively. DTA, DTS, ASI, SG, PASP and EASP are days to anthesis, days to silking, anthesis-silking-interval, stay green, plant aspect and ear aspect, respectively. 
Diallel Analysis of Maize inbred lines for agronomic traits...

TABLE 3

General combining ability of agronomic traits of the maize inbred line used in the diallel analysis for low $N$ tolerance under $N$ stress and optimal conditions

\begin{tabular}{lllllllllllc}
\hline \multirow{2}{*}{ Inbred line } & \multicolumn{9}{c}{ N stress condition } \\
\cline { 2 - 11 } & \multicolumn{1}{c}{ GY } & \multicolumn{1}{c}{ DTS } & ASI & \multicolumn{1}{c}{ SG } & PASP & $G Y$ & DTS & ASI & $S G$ & PASP \\
\hline TZEI13 & 90.43 & $1.097^{* *}$ & $0.292^{* *}$ & 0.131 & $0.156^{* *}$ & -38.65 & $1.019^{*}$ & -0.094 & $0.200^{*}$ & 0.035 \\
TZEI146 & 37.38 & $-0.686^{* *}$ & $-0.142^{*}$ & $-0.156^{*}$ & 0.031 & 44.46 & -1.314 & -0.311 & -0.164 & -0.099 \\
TZEI10 & -111.70 & $-0.586^{* *}$ & -0.075 & 0.017 & 0.006 & $-289.40^{*}$ & -0.281 & 0.006 & 0.017 & $0.143^{*}$ \\
TZEI12 & 140.80 & $0.881^{* *}$ & 0.008 & $-0.15^{*}$ & $0.089^{*}$ & $572.00^{* *}$ & $1.186^{*}$ & $0.306^{*}$ & $0.136^{*}$ & -0.407 \\
TZEI128 & 13.95 & $-0.769^{* *}$ & $0.142^{*}$ & -0.081 & $0.131^{*}$ & 12.19 & -0.597 & -0.011 & 0.006 & -0.024 \\
TZEI11 & $-1001.00^{* *}$ & $0.497^{*}$ & -0.008 & 0.058 & $0.331^{* *}$ & $-591.90^{* *}$ & $0.536^{*}$ & $0.172^{*}$ & $0.342^{*}$ & $0.460^{*}$ \\
TZEI8 & -89.35 & $-1.419^{* *}$ & $0.192^{* *}$ & $0.658^{* *}$ & 0.047 & $-380.60^{* *}$ & -1.247 & 0.006 & $0.319^{*}$ & $0.185^{*}$ \\
TZEI16 & 124.20 & $0.681^{* *}$ & $0.258^{* *}$ & -0.100 & $-0.094^{*}$ & 139.90 & $0.419^{*}$ & -0.161 & -0.147 & 0.060 \\
TZEI124 & $-222.10^{*}$ & -0.253 & -0.092 & $0.242^{* *}$ & $-0.086^{*}$ & 102.30 & -0.464 & -0.078 & -0.072 & -0.090 \\
BD74-165 & $327.10^{* *}$ & $-0.703^{* *}$ & $-0.292^{* *}$ & $-0.336^{* *}$ & $-0.236^{* *}$ & 125.80 & -0.481 & -0.078 & -0.092 & 0.035 \\
BD74-161 & $491.40^{* *}$ & $0.664^{* *}$ & -0.092 & $-0.275^{* *}$ & -0.078 & 110.30 & $0.486^{*}$ & $0.272^{*}$ & -0.461 & -0.065 \\
BD74-222 & $199.20^{*}$ & $0.597^{* *}$ & $-0.192^{* *}$ & -0.008 & $-0.294^{* *}$ & $204.70^{*}$ & $0.736^{*}$ & -0.028 & -0.49 & -0.232 \\
\hline
\end{tabular}

${ }^{*}$ and ${ }^{* *}$ are significant at $5 \%$ and $1 \%$ respectively.

GY, DTS, ASI, SG and PASP indicate grain yield, days to silking, anthesis-silking-interval, stay green and plant aspect, respectively. 
TABLE 4

Specific combining ability for some traits in the hybrid maize under varied $N$ conditions in 2014 and 2015

\begin{tabular}{|c|c|c|c|c|c|c|c|c|c|c|}
\hline \multirow{2}{*}{ Hybrid } & \multicolumn{4}{|c|}{$N$ stress condition } & \multirow[b]{2}{*}{$P A S P$} & \multicolumn{5}{|c|}{ Optimal condition } \\
\hline & $G Y$ & DTS & $A S I$ & $S G$ & & $G Y$ & DTS & $A S I$ & $S G$ & PASP \\
\hline TZEI13×TZEI146 & $744.8^{* *}$ & 0.80 & $0.37^{\circ}$ & -0.22 & -0.73 & 347.9 & 0.43 & 0.29 & 0.00 & $\begin{array}{l}-0.05 \\
\end{array}$ \\
\hline TZEI13×TZEI10 & -150.7 & -0.47 & -0.19 & $-0.67^{* *}$ & -0.20 & $-1165.0^{\circ *}$ & $1.23^{\circ}$ & 0.31 & -0.15 & $0.63^{\circ}$ \\
\hline TZEI13×TZEI12 & -330.0 & -0.77 & $-0.44^{\circ}$ & $1.33^{* *}$ & 0.05 & $1561.0^{* *}$ & 0.27 & $0.34^{*}$ & $0.67^{*}$ & -0.57 \\
\hline TZEI13×TZEI128 & $987.2^{* *}$ & 0.22 & -0.24 & -0.24 & -0.58 & $1037.0^{*}$ & 0.38 & 0.16 & 0.28 & -0.87 \\
\hline TZEI13 $\times$ TZEI11 & $-664.4^{*}$ & -0.22 & -0.09 & $0.43^{*}$ & $0.89^{*}$ & $-1566.0^{* *}$ & 0.42 & $0.64^{*}$ & -0.11 & $1.14^{\circ}$ \\
\hline TZEI13×TZEI8 & 363.4 & -0.47 & $0.54^{\circ}$ & 0.08 & -0.49 & $540.1^{*}$ & 0.03 & -0.36 & -0.23 & -0.58 \\
\hline TZEI13×TZEI16 & $-1317.0^{* *}$ & -0.07 & $-0.53^{\circ}$ & $0.78^{* *}$ & $0.73^{*}$ & $-2021.0^{* *}$ & 0.53 & -0.19 & -0.35 & $0.96^{\circ}$ \\
\hline TZEI13×TZEI124 & 420.3 & 0.87 & $0.82^{* *}$ & -0.23 & -0.03 & $583.0^{*}$ & -0.75 & -0.28 & -0.06 & 0.03 \\
\hline TZEI146×TZEI10 & -266.4 & $1.15^{\circ}$ & $0.41^{\circ}$ & $0.64^{* *}$ & $0.59^{*}$ & $-908.8^{*}$ & 0.73 & 0.02 & 0.19 & $0.68^{\circ}$ \\
\hline TZEI146×TZEI128 & 103.3 & -1.00 & $1.19^{* *}$ & $0.63^{* *}$ & -0.12 & $707.9^{*}$ & 0.55 & 0.37 & 0.70 & -0.32 \\
\hline TZEI146×TZEI11 & $-487.6^{*}$ & 0.90 & 0.34 & $-0.68^{* *}$ & 0.02 & $916.1^{* *}$ & 0.75 & $1.02^{*}$ & -0.47 & -0.64 \\
\hline TZEI146×TZEI8 & 145.1 & -0.02 & $-0.69^{\circ}$ & $-0.86^{* *}$ & -0.45 & $-562.3^{*}$ & 0.03 & $0.36^{*}$ & 0.22 & $0.55^{\circ}$ \\
\hline TZEI146×BD74165 & $564.6^{*}$ & -1.07 & $-0.38^{\circ}$ & -0.39 & $0.42^{*}$ & 311.6 & 0.27 & -0.06 & -0.01 & -0.63 \\
\hline TZEI146×BD74222 & $-1328^{* *}$ & $1.97^{\circ}$ & $0.69^{* *}$ & $0.92^{* *}$ & $0.39^{*}$ & $-1312.0^{* *}$ & 0.72 & 0.06 & 0.33 & $1.05^{\circ}$ \\
\hline TZEI10×BD74-165 & -76.0 & -0.50 & -0.28 & $0.49^{*}$ & 0.11 & $1017.0^{* *}$ & 0.23 & -0.54 & 0.00 & -0.12 \\
\hline TZEI10×BD74-161 & -116.8 & 0.47 & 0.19 & -0.15 & 0.12 & $-770.7^{*}$ & $1.93^{\circ}$ & -0.23 & 0.20 & $0.73^{\circ}$ \\
\hline TZEI10×BD74222 & $482.3^{*}$ & -1.30 & -0.04 & $-0.61^{*}$ & $0.25^{*}$ & 152.8 & -0.65 & $0.41^{*}$ & 2.41 & -0.02 \\
\hline TZEI12×TZEI11 & $-731.7^{*}$ & $1.17^{*}$ & 0.19 & 0.07 & 0.12 & $-623.3^{*}$ & $2.08^{\circ}$ & 0.24 & 0.00 & $0.58^{\circ}$ \\
\hline TZEI12×TZEI16 & -451.1 & $1.48^{*}$ & $0.76^{* *}$ & $-0.44^{*}$ & 0.55 & $-983.9^{*}$ & 0.70 & 0.24 & -0.84 & $0.32^{\circ}$ \\
\hline TZEI12×BD74165 & -114.8 & -0.30 & 0.31 & -0.34 & 0.11 & $-563.0^{*}$ & 0.10 & $0.49^{*}$ & 0.27 & -0.16 \\
\hline TZEI12×BD74161 & $1250.0^{\circ}$ & 0.17 & 0.27 & -0.38 & 0.20 & 260.1 & 0.80 & 0.14 & -0.58 & -0.31 \\
\hline TZEI128×TZEI8 & $-841.4^{*}$ & -0.10 & 0.02 & -0.13 & $0.95^{*}$ & -37.2 & 0.15 & $0.56^{*}$ & 0.02 & 0.06 \\
\hline TZEI128×TZEI124 & $-1287.0^{* *}$ & $1.23^{*}$ & -0.03 & -0.32 & $0.33^{*}$ & $-1014.0^{* *}$ & $1.53^{\circ}$ & 0.14 & -0.34 & $0.75^{\circ}$ \\
\hline TZEI128×BD74161 & $1275.0^{* *}$ & -0.18 & -0.19 & $-0.42^{*}$ & -0.09 & -898.1 & 0.25 & $0.79^{*}$ & -0.12 & -0.02 \\
\hline TZEI11×TZEI16 & $955.1^{* *}$ & -0.47 & -0.06 & 0.32 & -0.03 & -233.7 & 0.68 & $0.54^{*}$ & 0.01 & $0.37^{\circ}$ \\
\hline TZEI11×TZEI124 & $1243.0^{* *}$ & -3.20 & $-0.88^{* *}$ & 0.18 & $-0.37^{*}$ & 316.9 & -0.93 & -0.38 & 0.21 & -0.40 \\
\hline TZEI11×BD74161 & $930.6^{* *}$ & -0.62 & -0.04 & $-0.67^{* *}$ & -0.13 & $881.3^{* *}$ & 0.28 & -0.06 & -0.20 & -0.34 \\
\hline TZEI11 $\times$ BD74222 & $807.8^{* *}$ & -1.72 & $-0.61^{*}$ & $0.57^{*}$ & 0.09 & 920.4 & -1.97 & -0.26 & -1.55 & -0.26 \\
\hline TZEI8 $\times$ TZEI16 & 349.4 & -0.38 & -0.09 & 0.22 & 0.17 & $1110.0^{* *}$ & -0.87 & -0.96 & 0.48 & -0.44 \\
\hline TZEI $8 \times$ TZEI124 & $799.6^{* *}$ & 0.88 & 0.09 & $-0.51^{*}$ & -0.08 & -258.8 & -0.32 & $0.46^{*}$ & 0.24 & -0.29 \\
\hline TZEI $8 \times$ BD74165 & $-885.9^{*}$ & -2.83 & $-0.38^{*}$ & $0.66^{* *}$ & -0.02 & $-821.0^{*}$ & 0.03 & $0.46^{*}$ & 0.17 & $0.50^{\circ}$ \\
\hline TZEI124×BD74165 & $-986.9^{*}$ & 0.17 & $-0.93^{* \bullet}$ & $0.79^{* *}$ & $0.70^{*}$ & $-1293.0^{* *}$ & 0.92 & $0.54^{*}$ & $1.06^{*}$ & $0.94^{\circ}$ \\
\hline TZEI124×BD74161 & $-1259.0^{*}$ & $1.13^{*}$ & 0.21 & $0.76^{* *}$ & $0.71^{*}$ & $-934.8^{*}$ & $1.28^{\circ}$ & -0.14 & -0.12 & $0.38^{\circ}$ \\
\hline TZEI124×BD74222 & $689.9^{*}$ & 0.53 & $0.47^{\circ}$ & 0.33 & -0.41 & $910.9^{*}$ & -0.13 & -0.51 & -3.03 & -0.46 \\
\hline BD74165×BD74161 & $511.5^{*}$ & 0.75 & -0.09 & 0.06 & -0.56 & 422.5 & -0.87 & -0.14 & -0.85 & 0.08 \\
\hline BD74165×BD74222 & 424.0 & $0.98^{*}$ & 0.01 & $-0.43^{*}$ & -0.34 & $-662.0^{*}$ & $2.38^{\circ}$ & $0.49^{*}$ & 2.91 & 0.08 \\
\hline
\end{tabular}

*, and **, GY, DTS, ASI, SG and PASP are significant $(P<0.05)$ and $(\mathrm{P}<0.01)$, grain yield, days to silking, anthesis-silking-interval, stay green and plant aspect, respectively 
Diallel Analysis of Maize inbred lines for agronomic traits...

TABLE 5

Percentages of cross sums of squares contributed by GCA effects from female and male parents for selected traits of the maize evaluated in N stress and optimal conditions in 2014 and 2015

\begin{tabular}{|c|c|c|c|c|}
\hline \multirow{2}{*}{ Trait } & \multirow{2}{*}{$N$ condition } & $G C A_{f}$ & $G C A_{m}$ & $S C A$ \\
\hline & & \multicolumn{3}{|c|}{ Percentages of cross sums of squares } \\
\hline \multirow{2}{*}{ Grain yield } & Stress & 39 & 14 & 47 \\
\hline & Optimal & 30 & 10 & 60 \\
\hline \multirow{2}{*}{ Days to anthesis } & Stress & 38 & 33 & 30 \\
\hline & Optimal & 25 & 38 & 37 \\
\hline \multirow{2}{*}{ Days to silking } & Stress & 31 & 31 & 38 \\
\hline & Optimal & 24 & 35 & 41 \\
\hline \multirow{2}{*}{ Anthesis silking interval } & Stress & 12 & 13 & 75 \\
\hline & Optimal & 15 & 13 & 72 \\
\hline \multirow{2}{*}{ Plant height } & Stress & 44 & 20 & 36 \\
\hline & Optimal & 20 & 19 & 61 \\
\hline \multirow{2}{*}{ Ear height } & Stress & 29 & 17 & 54 \\
\hline & Optimal & 28 & 18 & 54 \\
\hline \multirow{2}{*}{ Stay green } & Stress & 18 & 34 & 48 \\
\hline & Optimal & 32 & 19 & 49 \\
\hline \multirow{2}{*}{ Plant aspect } & Stress & 19 & 28 & 53 \\
\hline & Optimal & 30 & 10 & 60 \\
\hline \multirow{2}{*}{ Ear aspect } & Stress & 12 & 26 & 61 \\
\hline & Optimal & 20 & 9 & 71 \\
\hline
\end{tabular}

$\overline{\mathrm{GCA} f}, \mathrm{GCA}_{m}$ and SCA indicate general combining ability for female, general combining ability for male and specific combining ability, respectively 